\title{
ANALYSIS OF THIRD PARTIES FUNDS AND INFLATION TO PROFITABILITY (Survey on Commercial Bank Shariah Period 2013-2018)
}

\author{
Ainul Fitri ${ }^{1}$ and Ersi Sisdianto ${ }^{2}$ \\ ${ }^{1}$ State Islamic University of Raden Intan Lampung, Bandar Lampung, \\ ainulfitri@radentintan.ac.id \\ ${ }^{2}$ State Islamic University of Raden Intan Lampung, Bandar Lampung, \\ ersisdianto@radenintan.ac.id
}

\begin{abstract}
This study aims to determine the effect of third-party funds and inflation on the profitability of Commercial Bank Sharia. The method of analysis in this study using multiple linear regression analysis. The population in this study are the financial statements of Commercial Bank Sharia. Based on the analysis that inflation and Third-Party Fund showed a significant effect on profitability. Limitations of this study are only discussing how much influence Third-Parties' funds and inflation on the profitability of Commercial Bank Shariah, as well as the number of samples and the population studied only Commercial Bank Shariah thus opening opportunities for new researchers with the same theme. The implications of this study are expected to be able to add to their repertoire of knowledge relating to the influence Third parties' funds and inflation on the profitability of Commercial Bank Sharia.
\end{abstract}

Keywords: Third parties funds, Inflation, Profitability.

\begin{abstract}
Abstrak. Penelitian ini bertujuan untuk mengetahui dampak dari pendanaan pihak ketiga dan inflasi pada tingkat keuntungan bank Syariah swasta. Metode analisa dari penelitian ini adalah multiple linear regression. Populasi dari penelitian ini adalah lampiran keuangan dari bank Syariah swasta. Berdasarkan dari analisa inflasi dan pendanaan pihak ketiga menunjukkan adanya dampak yang signifikan terhadap tingkat keuntungan. Batasan masalah dalam penelitian ini adalah mendiskusikan seberapa besar pengaruh dari pendanaan pihak ketiga dan inflasi terhadap keuntungan bank Syariah swasta, serta menjadi peluang baru bagi penelitian terhadap sejumlah sampel dan populasi yang dikaji pada bank Syariah swasta dengan tema yang sama. Dampak penelitian diharapkan dapat menambah khazanah pengetahuan mengenai pengaruh pendanaan
\end{abstract}


pihak ketiga dan inflasi terhadap tingkat keuntungan bank Syariah swasta.

Kata kunci: Pendanaan Pihak Ketiga, Inflasi, Tingkat Keuntungan.

\section{Preliminary}

According to Law No. 10 of 1998, the development of Islamic banks in Indonesia is growing rapidly, especially this era policy of banking law in Indonesia adheres to the banking system of dual (dual banking system), which provides an opportunity for a conventional bank provides Islamic services to first establish Sharia Business Unit (UUS). Thus, the existence of Islamic banking is legally recognized. But while people argue that with the rapid development of Islamic banking, the necessary arrangements about it through legislation. The law in question was approved and enacted the Law No. 1 of 2008 on the ratification of the influence of Islamic banking law 21 of 2008 greatly to the world economy of sharia, it is evident from the number of financial institutions Shariah principled stand. Starting from Islamic Banks (BUS), Sharia Business Unit (UUS), the People's Bank Syariah Financing (SRB), Cooperative sharia, Baitul Mall Watamwil (BMT), and other institutions that use its operating activities sharia principles. ${ }^{1}$

The function of Islamic banks was largely different from conventional banks, which are equally as intermediary (intermediary institution) that collects funds from the public and to channel back funds to those in need in the form of financing facilities ${ }^{2}$. fund raising is done through savings and investments, such as wadiah deposits, savings and time deposits, while distribution and done with some kind of agreement such as murabaha, istishna, mudaraba, musharaka, ijara and salam. ${ }^{3}$

Revenue devastating for the survival of the company, the greater the income, the greater the company's ability to finance all the expenses and activities to be undertaken by the company. Munandar said revenue is an increase of assets that increase the Owner's Euity, but not because of the capital increase of the owner, nor an increase of assets due to the increase in liabilities ${ }^{4}$.

For the result is one of the advantages of Islamic banking compared to the conventional banks because of the principles of Musharaka and mudaraba provide

\footnotetext{
2010)

${ }^{1}$ Dwi Suwiknyo, Analisis Laporan Keuangan Perbankan Syariah, (Yogyakarta: Pustaka Pelajar,

${ }^{2}$ Veithzal Rivai and Arviyan Arifin, Islamic Banking, (Jakarta: PT Bumi Aksara, 2010), p.29

${ }^{3}$ Dwi Nurapriyani, "Faktor-Faktor Yang Mempengaruhi Pembiayaan Murabah Di Bank Syariah Mandiri Periode Tahun 2004-2007." (Skripsi, Universitas Negeri Sunan Kalijaga., 2009)

${ }^{4}$ Satria, Dy Ilham, and Haryati Saputri, "Pengaruh Pendapatan Murabahah, Mudharabah dan Musyarakah terhadapa Return on Equity PT Bank Syariah Mandiri", Jurnal Visioner dan Strategis, Vol. 5 No. 2 (2016) ISSN: 2338-2864, p. 55-67.
} 
more benefits to the real sector. In this study focused on akad musyarakah that use profit and loss sharing compared mudharabah that use profit sharing.

Increase profabilitas should be accompanied by efforts to improve the quality of earning assets portfolio. One form of the distribution of productive assets in the Islamic banking through financing provided to the public. There are two main patterns is currently run by Islamic banks in the distribution of funding ${ }^{5}$ namely the principle of trading financing and financing with the principle of profit sharing. Financing with the principle of trading conducted by the Islamic banking scheme implemented into three forms, namely financing Murabahah, Salam, and Istishna. While financing with the principle of sharing is implemented in two forms namely Mudaraba and Musharaka financing.

Inflation is one of the macro-economic indicators that affect the socioeconomic conditions. The inflation rate may affect the economy and the performance of banks, primarily related to the allocation of credit / financing that has been given to customer financing. In the perspective of the manufacturer, the higher inflation then it will result in the increase in output in the market. The output price increase if it is not offset by the increase in people's income, it can suppress the sale of products on the market. So manufacturers will have difficulty selling goods in result. This condition can ultimately affect the company's financial performance, in which a portion of the existing funds are the proceeds of a bank loan. Thereby increasing the rate of inflation may lead the bank profabilitas be reduced, due to a number of credit/financing that has jammed ${ }^{6}$.

Profabilitas level of banks can be seen from how the bank's performance in managing the factors that may affect the achievement of profit. Total fund acquired an advanced bank deciding factor profabilitas level. The fund is a bankowned funds obtained from the public or the more commonly known as thirdparty funds. Third parties' funds are an important component for the bank to remain on operations. Third parties' funds, the funds raised by banks from the public, which consists of demand deposits, savings deposits and savings deposits ${ }^{7}$.

Profitability is the ability of the company makes a profit in relation to total sales, total assets and own capital. Third Parties Funds is a tool for investors and other users to view the financial performance of a bank. Third Parties Funds illustrates how much confidence customers to keep a portion of the funds (money) which has in a banking company. The higher Third Parties Funds of a bank, the greater the customer confidence in the bank, so that the funds allocated for operational activities such as lending bank will also increase. This will have an

${ }^{5}$ Ascarya., Akad \& Produk Bank Syriah, $1^{\text {st }}$ Ed., (Jakarta: Rajawali Press, 2015)

${ }^{6}$ Amalia Nuril Hidayati, 2014. "Pengaruh Inflasi, BI Rate dan Kurs Terhadap Profitabilitas Bank Syariah di Indonesia." Jurnal Ekonomi, Vol. 01, No. 1 (2014): 73-97.

${ }^{7}$ Kasmir, Etika Customer Service. (Jakarta: RajaGrafindo Persada, 2005) 
impact on improving bank earnings that would affect the bank's improved profitability. Capital adequacy is the ability of banks existing capital to cover possible losses in the credit or the trading of securities. The higher the CAR achieved by the bank showed the bank's performance the better because the bank is able to bear the risks that may arise. With the availability of sufficient capital by banks, bank operations will run smoothly and customer confidence in the bank increased so that the profits earned will increase. NPL is the rate of return on loans granted to the bank depositors in other words NPL is the level of bad loans in the bank. If the lower NPL, banks will increasingly experience the benefits, whereas if the high level of NPL of the bank will incur a loss due to the return of bad debts. NPL unnatural existence will lead to missed opportunities by banks to earn income from loans, thereby reducing the cost.

\section{Theoretical Basis}

\section{Agency Theory}

In agency theory explained that in a company there are two parties that interact with each other. These parties are the owners of the company (shareholders) and management companies. Referred to as the principal shareholder, while management person authorized by shareholders to run a company called agents. Companies that separate the functions of management and ownership would be vulnerable to conflicts agency caused by each of the parties have conflicting interests that they seek to achieve its prosperity alone. ${ }^{8}$ To minimize conflicts between them, the owners and management do contract work by regulating the proportion of the rights and obligations of each in order to achieve the expected utility. stated that the loan agreement is expected to maximize the utility owner, and can satisfy and guarantee management to receive a reward for the results management of the company. As for the benefits received by both parties is based on the company's performance.

The relationship between the owner and the management is very dependent on the assessment of the performance management owner. For that, the owner demanded the return on investment that is entrusted to be managed by the management. Therefore, management must provide satisfactory returns to the owner of the company, due to a good performance will be a positive influence on the compensation received, and otherwise poor performance will have negative effect. and can satisfy and guarantee management to receive a reward for the results management of the company. As for the benefits received by both parties is based on the company's performance. The relationship between the owner and the management is very dependent on the assessment of the

\footnotetext{
${ }^{8}$ Jensen, M., C., and W. Meckling, "Theory of the firm: Managerial behavior, agency cost and ownership structure", Journal of Finance Economic 3 (1976):305- 360.
} 
performance management owner. For that, the owner demanded the return on investment that is entrusted to be managed by the management. There fore management must provide satisfactory returns to the owner of the company, due to a good performance will be a positive influence on the compensation received, and otherwise poor performance will have negative effect. and can satisfy and guarantee management to receive a reward for the results management of the company. As for the benefits received by both parties is based on the company's performance. The relationship between the owner and the management is very dependent on the assessment of the performance management owner. For that, the owner demanded the return on investment that is entrusted to be managed by the management. Therefore, management must provide satisfactory returns to the owner of the company, due to a good performance will be a positive influence on the compensation received, and otherwise poor performance will have negative effect. The relationship between the owner and the management is very dependent on the assessment of the performance management owner. For that, the owner demanded the return on investment that is entrusted to be managed by the management. Therefore, management must provide satisfactory returns to the owner of the company, due to a good performance will be a positive influence on the compensation received, and otherwise poor performance will have negative effect. The relationship between the owner and the management is very dependent on the assessment of the performance management owner. For that, the owner demanded the return on investment that is entrusted to be managed by the management. Therefore, management must provide satisfactory returns to the owner of the company, due to a good performance will be a positive influence on the compensation received, and otherwise poor performance will have negative effect.

\section{Singnalling Theory}

The second theory that explains the importance of performance measurement is the theory of signal (signaling theory). Signal theory discusses how should signal- signal success or failure of the management (agent) is delivered to the owner (principal). Signal theory explains that giving the signal made by the management to reduce asymmetric information. The theory of signal to explain why companies have an incentive to provide financial information to external parties. ${ }^{9}$ The impulse arises because of the asymmetric information between companies (management) with the outside, where the company's internal information management knows relatively more and faster than outsiders such as investors and creditors. Lack of information obtained by outside parties about the company cause outsiders to protect themselves by giving a low

${ }^{9}$ Ratna Candra Sari and Zuhrotun, "Keinformatifan Laba di Pasar Obligasi dan Saham Uji Liquidation Option Hypothesis", Jurnal. Ilmiah Akuntasi dan Bisnis Vol. 3. No. 1 (2008). 
value for the company. Companies can increase the value of companies with 17 reduce asymmetric information, one way is to give a signal to the outside in the form of reliable financial information so as to reduce uncertainty about the company's prospects in the future. A report on the performance of companies that will either enhance shareholder value. In signaling theory, as for the motivation of present financial information management is expected to provide signal prosperity to the owners or shareholders.

\section{Definition of Third Parties Funds}

Third Parties Funds are funds obtained from the public, in the sense of people as individuals, companies, governments, households, cooperatives, foundations, and others both in rupiah and foreign currency. In most or all banks, public fund is the largest fund owned. This is consistent with the bank's function as raising funds from the public.

1. Wadi'ah demand deposits, Using the principle of Yad Dhamanah Wadi'ah. Demand deposits are deposits from the public both in rupiah or foreign currency at banks in their transactions (withdrawals and deposits) can be done at any time by check, current account, ATM card, pay orders of others or by overbooking. Current accounts include funds that sensitive or sensitive to changes, also called labile that any funds can be withdrawn or deposited by the customer. In this product uses wadi'ah yad dhamanah contract. Wadiah Yad Dhamanah is an agreement in which the parties entrust authorized and opportunity to those who entrusted goods to use the goods or funds deposited for specific purposes that benefit the restrictions upon the parties entrust the goods or funds needed, then the party who dititpi should be handed over intact. Entrusted parties remain entitled to a fee and if possible, give a bonus to those who left on gains over the use of goods or funds deposited. Things to keep in mind that bonuses should not be to agreed upon in the contract. Entrusted parties remain entitled to a fee and if possible, give a bonus to those who left on gains over the use of goods or funds deposited. Things to keep in mind that bonuses should not be to agreed upon in the contract. Entrusted parties remain entitled to a fee and if possible, give a bonus to those who left on gains over the use of goods or funds deposited. Things to keep in mind that bonuses should not be to agreed upon in the contract.

2. Mudharabah savings is a savings or third parties deposits in Rupiah or foreign currency at banks using mudharabah which at the beginning of the books will be agreed massive savings account for the results to be accepted. Mudharabah muthlaqah (Unrestricted Investment account), the form of cooperation between the maal and shahibul mudharib unconditionally or without being limited by the specifications of the type 
of effort, time, and area businesses. In English, the Islamic economists often refer to mudharabah muthlaqah as Unrestricted Investment Account (Uriah). So, when there is a loss in the business, mudharib not bear the risk of losses. Losses are fully addressed Shahibul maal.

3. Deposit are third parties' deposits in Rupiah or foreign currency, issued on behalf of the customer to the bank and can be withdrawn only at a specific time according to the agreement between the depositor and the bank. Time deposits including deposits on call are relatively short duration and can be withdrawn at any time with prior notice. In this product uses mudharabah mutlaqah.

Public funding (third parties funds) are funds from the public, whether individuals or businesses, which are obtained using various instruments denagn bank savings products owned by the bank. Public funding is the biggest fund owned by the bank and is consistent with the bank so fundraiser functionality of third-party excess funds in the society. The public funds collected by the bank with savings products as follows:

1. Demand deposits (demand deposits)

2. Deposits (time deposits)

3. Savings (saving).

According to Bank Indonesia Circular Letter No. 6/23 / DPNP May 31, 2004, deposits are deposits which may be withdrawn at any time 19 by check, current account, forms of payment order, or by transfer. Savings is may only be withdrawn under certain agreed conditions, but can not be withdrawn by check, demand deposit, and/or other tools are equivalent. And deposits are deposits that can be withdrawn only at a specific time based on the agreement the depositor and the bank. Third parties' funds are the largest funding source of the most relied upon by banks, deposits can reach $80 \%-90 \%$ of all funds managed by the bank. Activities of the bank after collecting funds from the public in the form of demand deposits, savings, and the deposit is returned channeling funds to communities that need it. ${ }^{10}$ This fund distribution activities also known as the allocation of funds. Allocating funds can be realized in the form of loans or more commonly known as a credit. ${ }^{11}$

\footnotetext{
${ }^{10}$ Lukman Dendawijaya, Manajemen Perbankan, $2^{\text {nd }}$ Ed., $2^{\text {nd }}$ Print, (Bogor: Ghalia Indonesia, 2005) 2008)

${ }^{11}$ Kasmir, Bank dan Lembaga Keuangan Lainnya, Revision Edition (Jakarta: PT. Raja Grafindo,
} 
Third parties' funds known by public funds; the funds raised by the Bank from the public. In the broadest sense, encompassing individual communities, and business entities Bank offers deposit products to the public in raising funds. ${ }^{12}$

Raising funds from the public conducted by a conventional bank is in the form of savings, deposits and Current account commonly known as the Third party's funds. In the Islamic banks raising funds from the public do not contrasted product name, but look on the principle that wadi'ah principle and the principle of Mudharabah. ${ }^{13}$

Survival of a bank conducting business based on sharia principles depending on the work, which one is the main indicator of the quality of the investment of bank funds. Quality good investments that will menghasilakn profits, so the performance of banks conducting business based on sharia principles would be good. All the bad quality of the investments that will bring the influence of declining performance of banks that may ultimately threaten the survival of a bank conducting business based on sharia principles. ${ }^{14}$

\section{Definition of Inflation}

Definition of inflation as follows: "Inflation is the increase in the prices of goods that are common and persistent". ${ }^{15}$ Meanwhile, according to Julius states that the definition of inflation as follows: "A short definition of inflation is the tendency of prices to rising continuously". ${ }^{16}$

Inflation is a general rise in the level of prices and goods/commodities and services during a specified time period. Inflation can be regarded as a monetary phenomenon due to impairment of the monetary calculation unit of a commodity. The definition of inflation by modern economists is the increase in the overall view of the amount of money that should be paid (monetary value calculation unit) for goods/commodities and services. ${ }^{17}$ Conversely, if what happens is the impairment of the monetary unit of account for goods/commodities and services is defined as deflation.

One that inflation is likely to decrease the balance of the welfare of individuals and society. Economic actors such as salaried workers who remain. Inflation usually run faster than the increase in wages of workers. Real wages of workers will decline due to inflation, and this means that the level of welfare or

${ }^{12}$ Ismail, Manajemen Perbankan, (Jakarta: Prenada Media Group, 2010)

${ }^{13}$ Muthaher Osmad, Akuntansi Perbankan Syariah, $1^{\text {st }}$ Print, (Yogyakarta: Graha Ilmu, 2012)

${ }^{14}$ Muhammad, Islamic Banking Management: A revised edition, (Yogyakarta: UPP AMP YKPN, 2004)

${ }^{15}$ Sadono Sukirno, Makro Ekonomi Teori Pengantar, $3^{\text {rd }}$ Ed. (Jakarta: Rajawali Pers, 2011)

${ }^{16}$ Julius R. Latumaerissa, Bank dan Lembaga keuangan Lain, (Jakarta: Salemba Empat, 2011)

${ }^{17}$ Adiwarman A. Karim, Ekonomi Mikro Islam, (Jakarta: PT Raja Grafindo Persada. 2007) 
prosperity most people will naturally fall to decline. So the adverse effects of inflation terhadapa individuals and society, namely:

1. Reduce real incomes for the people of fixed income

2. Reducing the value of wealth in the form of money

3. Worsen the distribution of wealth and memperebar chasm between income groups.

\section{Definition of Profitability}

According profitability is: earnings ratio is also called profitability illustrates the company's ability to profit through all of the capabilities and existing sources such as sales activities, cash, capital, number of employees, number of branches, and sebangainya. The ratio that illustrates the company's ability to generate profits also called Operating Ratio. Some types of profitability ratios or profitability, are as follows: ${ }^{18}$

1. Profit Margin (Profit Margin) This figure shows several large percentages of revenue generated from each sale. The greater this ratio, the better because it is considered the company's ability to get a high enough profit.

2. Asset turnover (return on assets) illustrates the asset turnover ratio measured by the volume of sales. The greater this ratio, the better. This means that the asset may be faster spins and profit.

3. Return on Investment (Return on Equity) This ratio indicates how many percent of the net profit obtained when measured from the owner's capital. The bigger the better. 4. Return on Total Assets This ratio indicates how much net profit obtained by the company as measured by the value of the assets.

4. Basic Earning Power This ratio indicates the ability of the company makes a profit is measured from the amount of earnings before deducting interest and taxes to total assets. The greater this ratio, the better.

5. Earning Per Share This ratio shows how much capacity per share profit.

6. Contribution Margin This ratio indicates the company's ability childbirth profit that would cover fixed costs or other operating costs.

The profitability ratio can also be described in terms of the ability of employees, branches, certain assets in profit.

Definition of profitability is as follows: "profitability or profitability is demonstrating the company's ability to generate profits for a certain period. Profitability of a company is measured by the success of the company and the

${ }^{18}$ Sofyan Syafri Harahap, Teori Kritis Laporan Keuangan, (Jakarta: Bumi Aksara, 2009) 
ability to use assets productively, thus the profitability of a company can be determined by comparing the income earned in a period by the number of assets or the amount of capital the company. "19

Profitability is as follows: "Profitability is the company's ability to obtain profit in relation to sales, total assets, and the capital itself." ${ }^{20}$ Based on the above definition can be seen that the profitability of a company's ability to earn income during the period or certain capital assets owned by the company. States that: "The level of income is an important factor of the company. The size of corporate profits can be determined through analysis of the company's financial statements by the ratio of profitability." ${ }^{11}$

\section{Research Methods}

In this study, the authors used the quantitative research where the process of extracting information embodied in the form of numbers as a tool to find information about what is known. Quantitative research emphasizes objective phenomena, and the maximization of objectivity, the study design was conducted using figures, statistical processing, structure and controlled trials. ${ }^{22}$ Quantitative research includes every type of research that is based on the calculation of the percentage, average, and other calculations. In other words, this study uses numerical computation or quantity. ${ }^{23}$

Based on the time this study was cross sectional research that is done in a certain time period and to collect data relating in order to find answers to research questions. ${ }^{24}$

\section{Population and Sample Research}

The population used in this research is all Commercial Bank Sharia period 2013 - 2018. According to Sugiyono defines a population as follows: "Population is the generalization region consisting of objects or subjects that have certain

\footnotetext{
${ }^{19}$ Munawir, Analisa Laporan Keuangan, (Yogyakarta: Liberty, 2014).

${ }^{20}$ Agus Sartono, Menejemen Keuangan Teori dan Aplikasi. $4^{\text {th }}$ Ed. (Yogyakarta: BPFE, 2010)

${ }^{21}$ Mohammad Nur Fauzi, "Pengaruh Kebijakan Dividen dan Pertumbuhan Perusahaan terhadap Struktur Modal dan Profitabilitas (Studi pada Sektor Mining yang Terdaftar Di Bursa Efek Indonesia Periode 2011-2013)" Jurnal Administrasi Bisnis (JAB), Vol. 24 No. 1 Juli 2015

${ }^{22}$ L.J. Moleong, Metodologi Penelitian Kualitatif Revision Edition, (Bandung: PT. Remaja Rosdakarya, 2011)

${ }^{23}$ Ibid p.6

${ }^{24}$ Uma Sekaran and Roger Bougie, Research Method for Business: A Skill Building Approach, $5^{\text {th }}$ Ed., (New York: John Wiley \& Sons, 2010).
} 
qualities and characteristics specified by the researchers to learn and then drawn conclusions." 25

The goal of this method is that the sample selected in accordance with the purpose of the research problem, thus minimizing errors in the data pemiihan process. In addition, due to considerations regarding the completeness of the data and the availability of data to be collected.

\section{Results and discussion}

Normality Test

Table 4.1

Normality Test Results

(Kolmogorov-Smirnov test)

\begin{tabular}{|c|c|c|c|}
\hline samples & $\begin{array}{r}\text { Kolmogorov- } \\
\text { Smirnov value z }\end{array}$ & significance & knot \\
\hline 14 & 0.799 & 0.547 & Ho \\
& & & accepted \\
\hline
\end{tabular}

Source: Data processed in 2019

The results of the test for normality (Kolmogorov-Smirnov test) in Table 4.2 above shows that the significance value of 0.547 suggesting that sigifikansi value is greater than $(a=0.05)$. Therefore it can be concluded that Ho is accepted, which means the data residuals normally distributed.

Test Multicollinearity

Table 4.2

Test Results Multicollinearity

(Test VIF)

\begin{tabular}{|l|c|c|}
\hline Independent variables & tolerance & VIF \\
\hline Third-party funds & 0,940 & 1,063 \\
\hline Inflation & .840 & 1,191 \\
\hline
\end{tabular}

Source: Data processed in 2019

${ }^{25}$ Sugiyono, Metode Penelitian Kuantitatif, Kualitatif dan R\&D, (Bandung: PT Alfabet., 2016). 
The test results multicollinearity (VIF test) in Table 4.3 show that VIF is less than 10 and more tolerance value of 0.10 , which means that the regression model is expressed not contain multicolinearity.

Test Heteroskidastity

\section{Scatterplot}

Dependent Variable: pendapatan musyarakah

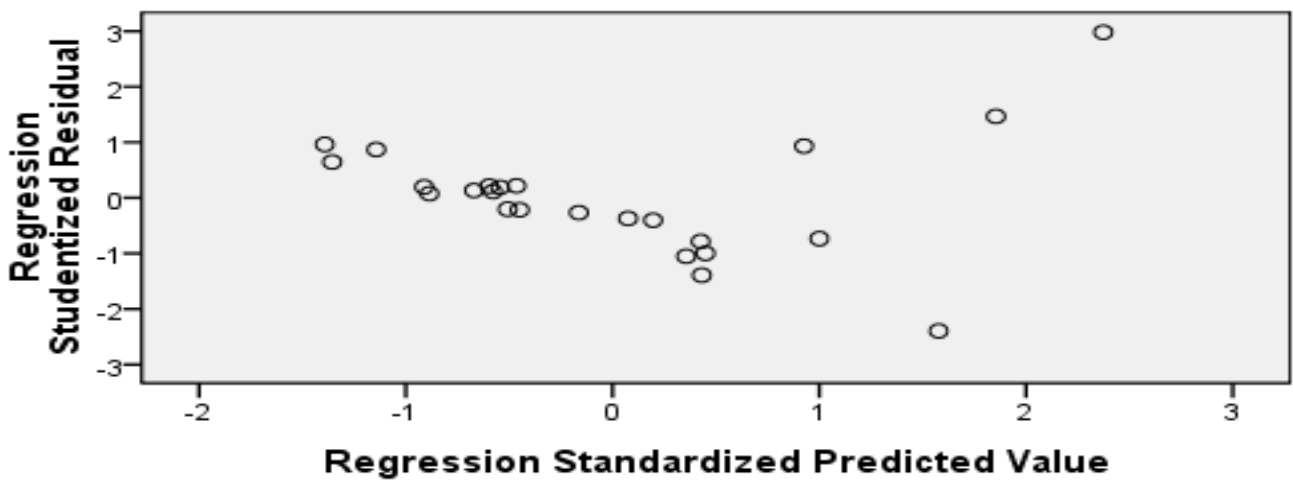

To detect the presence or absence of heteroscedasticity in the model can be seen from the model sccaterplot. There is no heteroscedasticity if:

1. The spread of dots should not be patterned

2. Spread the data dots above and below or under atu about the numbers 0 and 3

3. Data points not gather just above or below it. ${ }^{26}$

From the picture above shows dots spread randomly, do not form a particular pattern is clear. It can be concluded not occur heteroscedasticity in regression models is worth taking.

Autocorrelation Test

Table 4.4

Autocorrelation Test Results

(Test Runs Test)

${ }^{26}$ Agus Eko Sujianto, Aplikasi Statistik dengan SPSS 16.0. (Jakarta: PT. Prestasi Pustaka, 2009) 


\begin{tabular}{|c|c|c|}
\hline samples & Test Value & significance \\
\hline 14 & 254.18649 & 0.835 \\
\hline
\end{tabular}

Source: Data processed in 2019

Results autocorrelation test (test runs test) in Table 4.5 shows that the value of the test is 0.835254 .18649 with a significant probability of above 0.05 which means that the null hypothesis is accepted, so that it can be concluded that the residual random (random) or autocorrelation between the residual value.

Multiple Linear Regression Test

Table 4.5

Multiple Linear Regression Testing Results And The Regression Equation

\begin{tabular}{|c|c|c|c|c|c|}
\hline les $\quad$ variab & $\begin{array}{l}\text { Pred } \\
\text { iction }\end{array}$ & $\begin{array}{l}\text { Coef } \\
\text { ficient }\end{array}$ & metic & $\begin{array}{l}\text { Signifi } \\
\text { cance }\end{array}$ & $\begin{array}{l}\text { Inform } \\
\text { ation }\end{array}$ \\
\hline (Constant) & & $.870^{3072}$ & 0.357 & 0.725 & \\
\hline profitability & & & & & \\
\hline $\begin{array}{l}\text { Third-party } \\
\text { funds }\end{array}$ & + & $.480^{1067}$ & 3,347 & 0,003 & Be accepted \\
\hline Inflation & - & $3.872^{-}$ & -0.187 & 0.854 & Rejected \\
\hline \multicolumn{6}{|c|}{ R Square $=0,523$} \\
\hline \multicolumn{6}{|c|}{ adjusted $R 2=0,452$} \\
\hline$F$ coun & Sig = 7.318: & .002 & & & \\
\hline
\end{tabular}

Source: Data processed in 2019

Based on the regression equation shows that the constant has a positive regression coefficient direction that is equal to 3072.870 indicate if other variables increased $1 \%$ then the variable profitability increased by $307,287.0 \%$.

Based on the results of research and calculation of multiple linear regression test regression coefficient on the variable 1 which is positive third parties' funds amounting to 1067,480 means showing every $1 \%$ increase in inflation variable profitability increased by $106,748.0 \%$.

Based on the results of research and calculation of multiple linear regression test regression coefficient on the variable 3 that inflation is negative 
at -3.872 means that showed every decrease of $1 \%$ Inflation then Profitability decreased by $-387.2 \%$.

\section{Hypothesis Testing}

Testing the hypothesis that there is a partial influence inflation and ThirdParty Fund on profitability.

1. Effect of Third parties funds to Profitability

Based on the partial test results influence the Third parties funds to profitability in table 4.6 obtained $t$ count equal to 3,347 with $p$ value of 0.003 compared to significant level $(\alpha=5 \%)$, then $0.003<0.05$, because sig $<\alpha$ then concluded for the $\mathrm{H} 1$ meaningful receive third parties funds regression coefficient significant effect on profitability.

2. Inflation Influence on Profitability

Based on the partial test results Inflation influence to Profitability in table 4.6 above, the obtained $t$ count equal to -0.187 with $p$ value 0.854 compared to significant level $(\alpha=5 \%)$, then $0.854>0.05$, because sig $>\alpha$ it is concluded to accept Ho2 which means that the variable inflation does not significantly affect profitability.

\section{Effect of Inflation and Third Parties Funds to Profitability Commercial Bank Sharia}

From the result of $t$ test analysis coefficient table that has been done, it is known that the third party funding a significant effect on profitability in Commercial Bank Sharia and can be seen from the results of the regression coefficient values obtained 0,003 Third parties funds means that every increase of one unit, then Profitability will an increase of 0,003 units and has a positive influence or has a direct effect means higher third parties funds, the higher profitability of the Commercial Bank Sharia. This study therefore accept H1 accepted that third party funding significantly affect the profitability of Commercial Bank Shariah. This is evidenced by the results of the hypothesis test with significance value smaller than the value of $\alpha(0.003<0.05)$.

Output $t$ test illustrates the inflation variable does not affect the profitability of the Commercial Bank Shariah. This study therefore accept that the variable inflation Ho2 there is no significant effect on profitability in Commercial Bank Shariah. This is evidenced by the results of the hypothesis test with significance values greater than the value of $\alpha(0.854<0.05)$. Thus Ho2 stating that inflation variable is not significantly affect the profitability (accepted).

The results of this research together with research conducted by Trilianingsih (2018) third parties funds variable positive and significant impact 
on the profitability of Islamic banks. ${ }^{27}$ Pudji Astuti and M Nur Firdaus Rahman (2015) Also the result shows that the partial variable fund third parties with probability positive Significantly. ${ }^{28}$ These studies have the same result with research Ika Insyiroh (2015) The results of this study indicate that inflation has no significant effect on the profitability of Sharia Banks in the period from 2012 to $2014 .{ }^{29}$ and together with research conducted by the I Gede Putra Adyatmika and I Gusti Bagus Wiksuana (2018) Inflation and no significant negative effect on profitability. ${ }^{30}$ Research conducted by Amalia Nuril Hidayati (2014) has a difference where inflation has an influence on profitability. ${ }^{31}$

\section{Conclusion}

Based on the research data and analysis of the data in the study "Analysis of the Third party's funds and Against Inflation Profitability in Commercial Banks Shariah 2013-2018 "by using multiple linear regression and statistical tests can be concluded as follows:

a. Based on the regression coefficients third parties' funds significantly influence Profitability in Commercial Banks Shariah, Thus the higher third parties' funds will be followed by high profitability. For the H1 stating that the alleged third-party fund variables significantly influence the profitability acceptable. And Ho1 stating that the alleged inflation variable is not significantly affectProfitability in Commercial Banks Shariah rejected.

b. Based on the regression coefficient of inflation does not significantly affect the Profitability in Commercial Banks Shariah, thus increasing inflation it will not be followed by high profitability. For that Ho2 stating that inflation variable is not significantly affectProfitability in Commercial Banks Shariahbe accepted. And $\mathrm{H} 2$ which states that the inflation variable is not significantly affectProfitability in Commercial Banks Shariah rejected.

${ }^{27}$ Leny Trilianingsih, "Pengaruh Dana Pihak Ketiga (Dpk), Non-Performing Financing (Npf), Dan Inflasi Terhadap Profitabilitas (Roa) Dengan Pembiayaan Murabahah Sebagai Variabel Intervening Pada Bank Umum Syariah Di Indonesia (Periode 2013-2017)" (Skripsi, IAIN SALATIGA, 2018)

${ }^{28}$ Pudji Astuti and M Nur Firdaus Rahman, “Analisis Pengaruh Dana Pihak Ketiga, BI Rate, dan Kurs Rupiah Terhadap Profitabilitas (ROA) Pada Bank Persero di Indonesia Periode 20132018", (UIN Syarif Hidayatullah, 2015)

${ }^{29}$ Ika Insyiroh, "Pengaruh Inflasi Terhadap Profitabilitas”, (Skripsi, STAIN Kediri, 2015)

${ }^{30}$ I Gede Putra Adyatmika and I Gusti Bagus Wiksuana "Pengaruh Inflasi Dan Leverage Terhadap Profitabilitas Dan Return Saham Pada Perusahaan Manufaktur Di Bursa Efek Indonesia”, E-Jurnal Ekonomi dan Bisnis Universitas Udayana Vol. 7, No. 3 (2018):615-648

${ }^{31}$ Amalia Nuril Hidayati, "Pengaruh Inflasi, Bi Rate Dan Kurs Terhadap Profitabilitas Bank Syariah Di Indonesia", (IAIN Tulungagung, 2014.) 


\section{Reference}

Sujianto, Agus Eko Sujianto, Aplikasi Statistik dengan SPSS 16.0. Jakarta: PT. Prestasi Pustaka, 2009.

Sartono, Agus, Menejemen Keuangan Teori dan Aplikasi, $4^{\text {th }}$ Ed., Yogyakarta: BPFE, 2010.

Ali, Mohammad, Metodologi \& Aplikasi Riset Pendidikan, Jakarta: PT Bumi Aksara, 2014.

Hidayati, Amalia Nuril, "Pengaruh Inflasi, BI Rate Dan Kurs Terhadap Profitabilitas Bank Syariah Di Indonesia”, Tulungagung: IAIN Tulungagung, 2014.

Ascarya, Akad and Islamic Banking Products, $5^{\text {th }}$ Ed., Jakarta: PT. King Grafinda Persada, 2015.

Dendawijaya, Lukman, Manajemen Perbankan, $2^{\text {nd }} E d, 2^{\text {nd }}$ Printed, Bogor: Ghalia Indonesia, 2005.

Fauzi, Mohammad Nur, "Pengaruh Kebijakan Dividen dan Pertumbuhan Perusahaan terhadap Struktur Modal dan Profitabilitas (Studi pada Sektor Mining yang Terdaftar Di Bursa Efek Indonesia Periode 2011-2013).”, Jurnal Administrasi Bisnis (JAB), Vol. 24 No. 1 Juli 2015

Gede Putra Adyatmika and I Gusti Bagus Wiksuana, "Pengaruh Inflasi Dan Leverage Terhadap Profitabilitas Dan Return Saham Pada Perusahaan Manufaktur Di Bursa Efek Indonesia", E-Jurnal Ekonomi dan Bisnis Universitas Udayana, Vol. 7, No. 3, 2018:615-648

Harahap, Sofyan Syafri, Teori Kritis Laporan Keuangan, Jakarta: Bumi Aksara, 2009.

Hidayati, Amalia Nuril, "Pengaruh Inflasi, BI Rate dan Kurs Terhadap Profitabilitas Bank Syariah di Indonesia" Jurnal Ekonomi, Vol. 01 (1) 2014: 73-97.

Ika Insyiroh, "Pengaruh Inflasi Terhadap Profitabilitas", Kediri: STAIN Kediri, 2015.

Ismail, Islamic Banking, Jakarta: Penada Media Group, 2011

Jensen, M., C., and Meckling, W., “Theory of the firm: Managerial behavior, agency cost and ownership structure", Journal of Finance Economic 3, 1976:305- 360.

Latumaerissa, Julius R., Bank dan Lembaga keuangan Lain, Jakarta: Salemba Empat, 2011.

Karim, Adiwarman A., Macroeconomic Islam, Jakarta: PT Grafindo Persada, 2007.

Kasmir, Etika Customer Service, Jakarta: Raja Grafindo Persada, 2005. 
Kasmir, Bank dan Lembaga Keuangan Lainnya. Revition Ed. 2008. Jakarta: PT. Raja Grafindo, 2008.

Latumaerissa, Julius, Banks and Other Financial Institutions, Jakarta: Salemba Four, 2011.

Trilianingsih, Leny, "Pengaruh Dana Pihak Ketiga (Dpk), Non-Performing Financing (Npf), Dan Inflasi Terhadap Profitabilitas (Roa) Dengan Pembiayaan Murabahah Sebagai Variabel Intervening Pada Bank Umum Syariah di Indonesia (Periode 2013-2017)", Skripsi, Salatiga: IAIN Salatiga, 2018

Listianingrum, Fitri, "Effects of Inflation, Acquisition of Third parties' funds, and the Interest Rate Funding Against Trouble and Its Implication Profabilitas the SRB in Indonesia for January 2013- July 2016" Jakarta: State Islamic University Syarif Hidayatullah, 2017

Moleong, L.J., Metodologi Penelitian Kualitatif Edisi Revisi, Bandung: PT. Remaja Rosdakarya, 2011.

Muhammad, Islamic Banking Management: A revised edition, Yogyakarta: UPP AMP YKPN, 2004.

Muthaher, Osmad, Islamic Banking Accounting, Yogyakarta: Graha Science, 2012.

Munawir, Analisa Laporan Keuangan, Yogyakarta: Liberty, 2014.

Nurdin, Mohammad, "The Effects of Inflation, NPF and DPK Murabahah Against the Islamic Bank in Indonesia period 2011-2015" Jakarta: State Islamic University Syarif Hidayatullah, 2017.

Nurapriyani, Dwi, "Faktor-Faktor Yang Mempengaruhi Pembiayaan Murabah Di Bank Syariah Mandiri Periode Tahun 2004-2007.” Skripsi, Yogyakarta: Universitas Negeri Sunan Kalijaga, 2009.

Perdanasari, Petricia Yuni, "Analysis of Effect of CAR, NPF, FDR, ROA, BI Rate and Inflation Rate Profabilitas against Islamic Banking in Indonesia Period 20112017", Yogyakarta: Islamic University of Indonesia, 2018.

Reksoprayitno, Economic System and Economic Democracy, Jakarta: Graphic Development, 2004.

Astuti, Pudji and Rahman, M Nur Firdaus, "Analisis Pengaruh Dana Pihak Ketiga, BI Rate, dan Kurs Rupiah Terhadap Profitabilitas (ROA) Pada Bank Persero di Indonesia Periode 2013-2018", Jakarta: UIN Syarif Hidayatullah, 2015.

Satria, Dy Ilham, and Saputri, Haryati, "Pengaruh Pendapatan Murabahah, Mudharabah dan Musyarakah terhadapa Return On Equity PT Bank Syariah Mandiri", Jurnal Visioner dan Strategis, Vol. 5 No. 2, 2016, ISSN : 2338-2864, hlm. 55-67. 
Sari, Ratna Candra and Zuhrotun, "Keinformatifan Laba di Pasar Obligasi dan Saham Uji Liquidation Option Hypothesis", Jurnal Ilmu Akuntasi dan Bisnis, Vol. 3, No. 1, 2008.

Sugiyono, Quantitative Research Methods, Qualitative and R \& D, Bandung: Alphabet. CV, 2016.

Sukirno, Sadono, Makro Ekonomi Teori Pengantar $3^{\text {rd }}$ Ed., Jakarta: Rajawali Pers, 2011.

Sujarweni, V. Wiratna, Business \& Economic Research Methods, Yogyakarta: New Library Press, 2015.

Surfen, Jonathan Nathaniel, Belajar Self-taught SPSS Pasti Bisa, Jakarta: PT Elex Media Komputindo, 2014.

Suwiknyo, Dwi, Analisis Laporan Keuangan Perbankan Syariah, Yogyakarta: Pustaka Pelajar, 2010.

Sekaran, Uma, and Bougie, Roger, Research Methods for Business: A Skill Building Approach $5^{\text {th }}$ Edition, Chicester: John Wiley \& Sons, Ltd., 2010.

Winarno, Wing Revelation, Econometrics and Statistical Analysis with Eviews, Yogyakarta: UPP STIM YKPN, 2017.

Rivai, Veithzal and Arifin, Arviyan, Islamic Banking, Jakarta: PT Bumi Aksara, 2010.

The Government of Indonesia. 1998. Statutes No. 10 Year 1998

The Government of Indonesia. 2008. Statutes No. 1 Year 2008. Jakarta

The Government of Indonesia. 2008. Statutes No.21 Year 2008. Jakarta

Circular of Bank Indonesia No. 6/23/DPNP dated $31^{\text {st }}$ May 2004. Jakarta. 